Check for updates

Doctors of the World

Cite this as: $B M J 2022 ; 376: 0165$ http://dx.doi.org/10.1136/bmj.0165 Published: 20 January 2022

\title{
The UK's immigration plans threaten the health outcomes of asylum seekers and refugees
}

\begin{abstract}
Matteo Besana and colleagues urge the government to scrap the Nationality and Borders Bill, which poses serious threats to the health and wellbeing of people going through the asylum system
\end{abstract}

\section{Matteo Besana, Yusuf Ciftci, Thabo Makuyana}

The Nationality and Borders Bill making its way through UK Parliament has received severe criticism in the past few months, ${ }^{1}$ but there has been little discussion of its implications for the health of people seeking refugee protection in the UK.

Priti Patel, the home secretary, has said that the main motivation behind this bill is to fix an asylum system that is broken. Yet the system was never broken, it actually did and is still doing what it was designed to do: to create a hostile environment for people seeking refuge. This bill will be the latest addition to a series of policies that restrict people's access to asylum and ensuing ability to lead meaningful lives in UK communities. It will also prevent people in vulnerable circumstances from accessing essential health and wellbeing services. We think that two outcomes of the bill in particular will have a harmful impact on health: its creation of more people with temporary immigration statuses and the planned greater use of institutional accommodation for those seeking asylum.

\section{The risks of temporary immigration status}

The bill lays out a two tier asylum system depending on how people enter the UK. Those who arrive through a visa or resettlement route would be given the refugee protection they are entitled to under the 1951 UN Refugee Convention. However, people who arrive by their own means (for example, by crossing the channel in a lorry or small boat) will be considered inadmissible to the UK asylum procedure. Inadmissible cases will only be considered if they cannot be removed from the UK, and even if their cases are granted, they would be given a "temporary protection status," which has lesser entitlements than the refugee status. A temporary protection status will not include, for example, an automatic right to settle in the UK, family reunion rights will be restricted, and there will be no guarantee that a person can access welfare support except in cases of destitution.

Having more people with a temporary immigration status will exacerbate the ongoing barriers that prevent asylum seekers and refugees from accessing health and social care services. The government's previous policies aimed at creating a hostile environment already forced many public sector workers into the role of an untrained, ill advised "border guard." Unfortunately, this happened in the health sector too when the government tightened rules on charging "overseas visitors" for certain kinds of healthcare treatment in 2015. Hospitals now have immigration status checks, and people's information can be shared between the NHS and the Home Office if the NHS wants to check a person's immigration status or if they owe money for treatment.

The bill currently under discussion in Parliament will increase the number of people who have temporary protection status and the length of time they're living with this temporary status. The sweeping change from being given international protection as a refugee, which lasts for five years, to a temporary protection status, which is only for up to 30 months, will create insecurity and exacerbate existing health inequalities. Evidence shows that refugees and asylum seekers, despite being entitled to free healthcare, already face wrongful refusal of GP registration and ongoing social, psychological, and cultural barriers to accessing care. ${ }^{2}$ It is unclear what will happen to people after the expiry of their initial temporary protection status. There is a real risk of them becoming undocumented, with all the known and numerous barriers that creates to accessing healthcare. ${ }^{3}$

\section{Greater use of institutional accommodation}

Secondly, the bill also introduces a new plan for accommodating people seeking asylum using a reception centre model. The existing accommodation system is based on using institutional sites or places of business, such as military barracks or hotels, many of which are in remote areas in rural settings or non-residential areas where there are less health services available. The current accommodation system is known to undermine people's ability to access appropriate healthcare. ${ }^{4}$ People seeking asylum are given no direct support to facilitate registering with a GP and, as a result, the vast majority are not registered with a GP, do not have an NHS number, and are unable to access many NHS services, including covid-19 services. ${ }^{4}$ The tendering process for these new reception centres means that they will likely also be in crowded, possibly remote settings.

Based on our experiences of the existing accommodation system and its failings, Doctors of the World have raised concerns ${ }^{5}$ that the new plan for reception centres will cause confusion about the healthcare rights and entitlements available for asylum seekers, barriers to them accessing healthcare services, problems for secondary care referrals, disruption to continuity of care, and worse physical and mental health outcomes as a result of living conditions.

Experiences of the past 18 months are instructive of the problems the new reception centres could create. 
For example, when the Home Office opened accommodation sites for a significant number of asylum seekers at the military site Penally in September 2020, the local health board was given only two working days' notice of the decision. ${ }^{6}$ The pressure was on local NHS commissioners to mobilise local services, some of which had no previous experience of caring for people seeking asylum.

The outbreaks of covid-19 at Napier Barracks, particularly the nearly 200 people who tested positive in an outbreak in January 2021, ${ }^{7}$ exemplify how institutional asylum accommodation not only prevents people from registering with a GP and accessing covid-19 services, but how it also facilitates the spread of coronavirus by preventing residents from socially distancing and taking other precautionary measures. And yet this model, shown to be a public health risk, will be adopted on a much larger scale, with yet unknown implications for both the residents of these new reception centres, as well as for the communities in their proximity.

\section{An already harmful system}

The UK asylum system itself already contributes to poor health and wellbeing. A report from the Equality and Human Rights Commission found that for people seeking asylum, the asylum system and dispersal accommodation policy "conflicts with, and takes priority over, healthcare needs and access to services." ${ }^{8}$ The new bill will expand on the failings seen at contingency asylum accommodation sites, such as Napier and Penally. The independent chief inspector of borders and immigration has identified the "inadequate assessments of the physical and mental health of those selected to be moved to the camps" and "poor communication with the camp residents" that were found in inspections of these sites conducted between November 2020 and March 2021. ${ }^{9}$ We should be scrapping a model that has been found to fail asylum seekers, as well as posing serious threats to their health and wellbeing, not replicating it on a much larger scale.

The new bill's greater rollout of both temporary protection status and a flawed accommodation system will create room for discrimination, as well as increasing health inequalities. This flies in the face of one of the biggest lessons of the pandemic-namely, that only when everybody is protected is each and every one of us protected.

We urge the government to scrap this bill due to the detrimental impact it will have on the health and wellbeing of people going through the asylum system. Additional steps need to be taken immediately to review the accommodation policy by replacing the plans to establish reception centres and its institutional accommodation model with a community housing model of accommodation. Placing asylum seekers within established communities gives them meaningful access to health services, prevents further workload for local services, and minimises public health risks to the wider community.

Competing interests: none declared.

Provenance and peer review: not commissioned; not peer reviewed.

Nationality and Borders Bill. UK Parliament. Updated 19 January 2022. https://bills.parliament.uk/bills/3023

2 Registration refused: A study on access to GP registration in England. Doctors of the World. 2018. https:/www.doctorsoftheworld.org.uk/wp-content/uploads/2019/08/Registration-Refused-final.pdf

3 Delays \& Destitution: An Audit of Doctors of the World's Hospital Access Project (July 2018-20). Doctors of the World. October 2020. https:/www.doctorsoftheworld.org.uk/wp-content/uploads/2018/11/Delays-and-destitution-An-audit-of-Doctors-of-the-Worlds-Hospital-Access-ProjectJuly-2018-20.pdf
$4 \quad$ Written evidence submitted by Doctors of the World, the Helen Bamber Foundation, Forrest Medico-Legal Services and Freedom from Torture (CORO245). Asylum Accommodation: clinical harm caused by the use of barracks as housing for asylum seekers. UK Parliament. 1 February 2021. https://committees.parliament.uk/writtenevidence/22982/html/

5 Policy Briefing on New Plan for Immigration and the Nationality and Borders Bill. 2021. Doctors of the World. 2021. https://www.doctorsoftheworld.org.uk/wp-content/uploads/2021/11/DOTWBriefing-for-the-new-Immigration-Plan-and-the-Bill.pdf

6 Moore S. Health Response to the use of the MOD Training Camp at Penally for Men Seeking Asylum in UK. Quality, Safety \& Experience Assurance Committee. 13 November 2020.

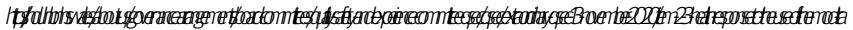

7 Bulman M. Covid outbreak at controversial camp housing hundreds of asylum seekers. The Independent. 11 August 2021. https://www.independent.co.uk/news/uk/home-news/covid-napierbarracks-asylum-seekers-home-office-b1900699.html

8 The lived experiences of access to healthcare for people seeking and refused asylum. Equality and Human Rights Commission. 2018. https://www.equalityhumanrights.com/sites/default/files/research-report-122-people-seeking-asylum-access-to-healthcare-lived-experiences.pdf

9 An inspection of contingency asylum accommodation: HMIP report on Penally Camp and Napier Barracks (November 2020 - March 2021). Independent Chief Inspector of Borders and Immigration. July 2021. https://assets.publishing.service.gov.uk/government/uploads/system/up loads/attachment_data/file/1005065/An_inspection_of_contingency_asylum_accommodation_HMIP_report_on_Penally_Camp_and_Napier_Barracks.pdf 